\title{
Entrepreneurship Education Program (EEP) Activities to Improve the Entrepreneurship Attitudes and Business Attitudes of the Entrepreneurs and Batik Artisans in Surakarta and Sragen
}

\author{
ASRI LAKSMI RIANI \\ Magister of Management Program, Faculty of Economy UNS Surakarta, Jl. Ir. Sutami 36A Kentingan Surakarta \\ 57126 \& PPkwu-LPPM-UNS \\ E-mail: asrilaksmiriani@yahoo.com
}

\begin{abstract}
EEP (Entrepreneurship Education Program) is an entrepreneurship education program that intended to influence the future individual entrepreneurship behavior and improve business success. The purpose of this activity is to increase motivation for entrepreneurial learning, gain an understanding of the importance of creativity and innovation, and production management in doing business in its field in order to improve its performance. This activity is carried on industry partners, entrepreneurs, and batik artisans in the region of Surakarta and Sragen. Production management training is done in batik industries in Laweyan village, whereas motivational training (outbound training) performed on batik industries in Kauman village, while the production creativity training is done on entrepreneurs and batik artisans in the village of Pilang, Sragen. Training results indicate a positive response to the training program given.
\end{abstract}

Keywords: EEP, production management training, outbound training, training creativity production

\section{INTRODUCTION}

EEP is an entrepreneurship education program that is intended to influence the future individual entrepreneurship behavior and improve the business success. The program aims to increase the interest of entrepreneurs to entrepreneurial careers and to raise awareness among public officials about the importance of entrepreneurship as a contributor to economic development (Hytti and Kuopusjrvi, 2004 in Fayolle et al., 2006 [1]). Entrepreneurship education is an education to promote entrepreneurship by influencing attitudes, values, and culture of the general public. This goal is the driving force behind all other purposes, i.e. startups, entrepreneurship, job creation, advancement of knowledge, and development of skills (Mwasalwiba, 2010 [2]).

In assessing the impact of EEP, this research refers to the theory of planned behavior. This theory is used in different contexts, places, and populations to assess the intentions and behavior, and now has been used to evaluate the EEP (Fayolle et al., 2006 [1]). Cruz et al. (2009) [3] proposed a model in which the EEP has direct effect on performance and satisfaction, and that innovation is an important aspect of entrepreneurship.

The program is carried on business partners of entrepreneurs and batik artisans in the region of Surakarta and district of Sragen, who have a business at least for one year. Limitation and formulation of the problem in this activity will develop the procedures, instruments, and modules of EEP models on the performance of entrepreneurs, especially those of businessmen and batik artisans in the mentioned region.

Problems faced by partners are:

1) The batik artisans and entrepreneurs' lack of motivation to develop.

2) The lack of creativity on the work created and owned by businessmen and batik craftsmen.

3) Lack of ability possessed by the batik artisans in the production field. 
4) Entrepreneurial activity has not been running optimally. This is indicated by the sustainability of entrepreneurial activity that is not guaranteed, and market share for the products produced are still small.

Targets and outcomes in the implementation of this community service program include:

1) Entrepreneurs and batik artisans have competence in the production management field.

2) Entrepreneurs and artisans have achievement motivation.

3) Entrepreneurs and artisans have the ability to create creative designs on the products created.

Entrepreneurship education intends to influence attitudes, values, and culture of the general public to promote entrepreneurship. It serves as the driving force for other purposes, such as start-up companies, job creation, advancement of knowledge, and skills development (Mwasalwiba, 2010 [2]). Fayolle et al. (2006) [1] state that assessing the effects of the EEP can be done by referring to the theory of planned behavior. This theory has been used in different contexts, places, and populations in assessing intentions and behavior and evaluating the EEP. In particular, this study shows how the EEP affects the three main factors of the theory of planned behavior that is attitude toward the behavior, subjective norm, and perceived behavioral control.

In Africa, entrepreneurship has existed since time immemorial. Barter trade existed in and along the African coast before the money economy came into existence (Otunga, 2001 [4]). In Kenya, for instance people engaged in exchange of goods such as beads, pottery, fish, basketry, and grains. With the coming of the money economy, entrepreneurs emerged among several African communities. To survive in the modern economy and in a globalized world, there is need for every African country to build capacity in the important field of entrepreneurship education and training (Nafukho \& Muyia, 2009 [5]). An entrepreneur has been described in terms of having desire for achievement in any activity that one is engaged in (McClelland, 1961 [6]), being proactive instead of reactive (Miller, 1983 [7]), having tolerance for ambiguity (Betaman and Crant, 1993 [8]; Schere, 1982 [9]), being innovative and creative (Drucker, 1985 [10]), being able to take risks (Brockhaus, 1980 [11]), being an opportunity identifier (Venkataraman,
1997 [12]), moderate risk takers (Sexton and Bowman, 1984 [13]), and having an internal locus of control (Brockhaus, 1982 [14]; Rotter, 1966 [15]). The best way to define an entrepreneur is by providing some examples of entrepreneurs.

\section{IMPLEMENTATION METHOD}

From the stages of activity according to Thiagarajan (1974) [16], the activity program is carried out in three phases to solve the problems that have been identified above. Stages of the activities performed are:

Stage I: Identify needs, problems, and the potential of entrepreneurs and batik artisans.

Identification intendeds to identify potential, strengths, weaknesses, opportunities that are associated with business units or activities undertaken, and the challenges faced, by considering the competitors in their environment. This identification is done to determine training materials, treatment materials needed by employers and batik artisans.

Stage II: Materials preparation and training: This stage aims to improve the ability of human resources (HR), in this case, the batik artisans and entrepreneurs, soft-skills and hard-skills in form of debriefing materials or instructional practices to improve production management, achievement motivation, and mental attitude of entrepreneurship, as well as creativity on the product design. These activities are expected to enhance the ability of batik artisans in the form of strengthening management and business activities development, in order to improve performance, achieving the business improvement through their entrepreneurial activity, and the advent of independence in their business.

Stage III: Monitoring: This stage aims to monitor the results of the implementation of the training with material on production management, creativity, and entrepreneurship. This stage also identifies the obstacles that arise during the training. Batik artisans and entrepreneurs are expected to have competent HR, develop their business, and the performance of individual crafters can be improved.

Stage IV: Evaluation: In order to determine the success of all these activities, it is necessary to conduct evaluation, based on the steps being taken:

1) Evaluation of stage I:

At this activity stage, an indicator of success is:

a. Availability of data about the potential, strengths, weaknesses, opportunities 
related to the activities undertaken, as well as the challenges faced by batik artisans and entrepreneurs in the partner regions.

b. The training materials structure and content are appropriate with the needs of batik artisans and entrepreneurs partners.

c. Human resources who give training have appropriate background in the field that is required by the learning partners - crafters and entrepreneurs.

2) Evaluation of stage II:

In this activity stage, the evaluation performed after the training is given. Indicators of success of activities in phase II are the HR, entrepreneur and batik artisans, which had been trained in production management, creativity, and entrepreneurship, have mastering the material given.

3) Ealuation of stage III:

Evaluation of phase III is the final stage of evaluation. The evaluation of the final stage is conducted to determine the results achieved after training. Indicators of success in this stage are:

a) There is an increase in the HR quality of entrepreneurs and batik artisans in the field of production management.

b) Entrepreneurs and batik artisans are capable to make more creative creations in batik design.

c) Managers have the knowledge and understanding to run and develop the business.

The final evaluation also identifies barriers that arise during the activity, and try to find a solution. It is expected with these three evaluation steps, that these activities can achieve the objectives set.

\section{RESULTS AND DISCUSSION}

\subsection{Discussion on Benefits of Program Implementation}

\subsubsection{Benefits for the entrepreneur and batik artisans partner}

Benefits for entrepreneurs and artisans after the training, with the material on production management, creativity, and entrepreneurship are as follows: a) Capable to run and develop entrepreneurial activities with adequate managerial capability.

b) Developing creativity and production capability.

c) Increasing achievement motivation.

\subsubsection{Benefits for College}

a) An opportunity for universities to play an active role in community development, including the development of small businesses.

b) As a form of implementation of the knowledge that had been presented to the stakeholders, so that the community in need can take a benefit from it.

c) Expanding the network of community service activities in cooperation with other parties.

\subsection{Discussion on the Target and Outcomes, as well as the Indicators of achievements}

The targets and output formulated in these communities service activities are: the HR, batik entrepreneurs and artisans have competence in the field of production management, creativity, and entrepreneurship. Through the evaluation of phase III it is shown that there is improvement on the quality of HR by 60 percent achievement of success. This is shown from the implementation of management and entrepreneurship by batik entrepreneur and artisans after the training and mentoring.

\section{CONCLUSION}

Based on the results achieved in the implementation of the EEP Program, which has been applied on batik entrepreneurs and artisans located in Sragen and Surakarta, the following conclusions can be drawn up:

1. The HR, batik entrepreneurs and artisans have competence in the field of production management.

2. Entrepreneurs and batik artisans have entrepreneurial managerial insight.

\section{REFERENCES}

[1] Fayolle, A., Gailly, B., and Lassas-Clerc, N. Assessing the impact of entrepreneurship education programmes: a new methodology. 
Journal of European Industrial Training. Vol. 30 No. 9, 2006. pp. 701-720

[2] Mwasalwiba, E.S. Entrepreneurship education: a review of its objectives, teaching methods, and impact indicators. Education + Training. Vol. 52 No. 1, 2010. pp. 20-47.

[3] Cruz, NM; Isabel REA; Barahona JH; Leitao FS. The Effect of Entrepreneurship Education Programmes on Satisfaction with Innovation Behaviour and Performance. Journal of European Industrial Training 33.3 2009: 198214.

[4] Otunga, R. N. Women enterprises in Eldoret Town: Their socio-economic background and business performance. In P. O. Alila, P. O. Pedersen, (Eds.), Negotiating social space: East African micro-enterprises. 2001. Trenton N.J.: Africa World Press Inc.

[5] Nafukho, FM and Muyia, MAH. Entrepreneurship and socioeconomic development in Africa: a reality or myth? Journal of European Industrial Training. Vol. 34 No. 2, 2009. pp. 96-109.

[6] McClelland, D.C. The Achieving Society, 1961. D. Van Nostrand Company, Inc., Princeton, NJ.

[7] Miller. The Correlated of Entrepreneurship in Three Types of Firms. Management Science, Vol. 29, 1983. pp. 770-791.

[8] Betaman T.S, and Crant J.M. The Proactive Component Organizatitonal Behavior: Measure and Correlates. Journal of Organizatitional Behavior. Vol 14 Issue 2. 1993. pp 107-118.

[9] Schere, J. Tolerance of Ambiguity as a Discriminating Variable betwee Entrpreneurs and Managers. Prociding of the Academy of Management. 42, 1982.pp.404-408

[10] Drucker, P.F. Innovation and Entrepreneurship, 1985. Heinemann, London.

[11]Brockhaus, R.H. "Risk taking propensity of entrepreneurship", Academy of Management Journal, Vol. 23 No. 3, 1980. pp. 509-20.

[12] Venkataraman, S." The distinctive domain of entrepreneurship research", Entrepreneur Theory and Practice, Vol. 4 No. 7, 1997. pp. $34-45$.

[13] Sexton and Bowman. Personality Inventory for Potential Entrepreneurs and Smaal Business Owners in New Venture Formation in JA Hornadey, F Tarplay, JA Timmons, and KH Vesper (eds). Frontier of Entrepreneurship Research, Bapson Center for Entrepreneurial Studies, 1984. Wallesley, Mass.

[14] Brockhaus, R.H. "The psychology of the entrepreneur", Encyclopedia of
Entrepreneurship, Prentice-Hall, Englewood Cliffs, NJ, 1982. pp. 39-56.

[15]Rotter, J.B. Generelized Expenctancy for Internal Versus Eksternal Control of Reinforcement, Psycologycal Monograph: General and Applied. Vol.80 no. 1; 1966. pp. $1-28$.

[16] Thiagarajan, S., Semmel, D. S \& Semmel, M. I. Instructional Development for Training Teachers of Expectional Children. Minneapolis, Minnesota: Leadership Training Institute/Special Education, 1974. University of Minnesota. 